\title{
BALANCE SCORECARD SEBAGAI PENGUKURAN KINERJA PADA PERGURUAN TINGGI
}

\author{
Umaimah \\ umaimahumg@gmail.com \\ Fakultas Ekonomi dan Bisnis Universitas Muhammadiyah Gresik
}

\begin{abstract}
Abstact
The purpose of this study was to analyze the performance of the university with the balanced scorecard. This study was included in the category of qualitative research.The results showed, based on measurements of four perspectives; growth and learning, internal business processes, customers, and finance, the university has done a good performance so apparent value increased in a positive ROI.
\end{abstract}

\section{Keywords: Balanced Scorecard, Performance, Higher Education}

\section{PENDAHULUAN}

Perusahaan saat ini berada pada lingkungan yang dinamis yaitu berada di tengah-tengah abad informasi dimana perubahan terjadi sangat pesat dan menuntut perusahaan untuk bisa bersaing menuju masa depan. Paradigma baru telah mengantarkan perguruan tinggi pada orientasi persaingan bukan hanya pada level nasional, orientasi perguruan tinggi kini telah bergeser pada persaingan antar perguruan tinggi secara global. Fakta kekinian menunjukan banyak perguruan tinggi asing yang masuk ke Indonesia bukan lagi sebatas studi banding atau menjalin kerjasama, namun melakukan promosi besar besaran (Hamid:2013) dalam seminar "Membangun Brand dan Trik Jitu Perguruan Tinggi Mandiri, Berkualitas Menuju Word Class University.

Menghadapi lingkungan yang dinamis dimana perubahan terjadi sangat pesat, maka perusahaan memerlukan pertimbangan terbaik di dalam membawa perusahaan atau organisasi menuju masa depan yang lebih baik. Suatu sistem penilaian kinerja berusaha untuk memenuhi kebutuhan dari pihak pemangku kepentingan (stakeholders) yang berbeda dari organisasi perusahaan dengan menciptakan campuran dari ukuran-ukuran strategis: ukuran hasil dan pemicu, ukuran keuangan dan non keuangan, serta ukuran internal dan eksternal (Anthony dan Govindarajan, 2005:173).

Fakta di Indonesia menunjukkan bahwa kualitas sebagian Perguruan Tinggi Swasta (PTS) memprihatinkan. Kementerian Riset Teknologi dan Pendidikan Tinggi telah menutup 10 Perguruan Tinggi di Jawa Timur pada Desember 2015 dikarenakan tidak memenuhi syarat sesuai ketentuan. (https://nasional.tempo.co/read/73026 6/pemerintah-tutup-10-perguruantinggi-swasta-di-jawatimur/full\&view=ok, diakses tanggal 2 Juli 2016). Perguruan Tinggi Swasta dinyatakan legal bila memenuhi enam syarat. Syarat tersebut adalah; memiliki akta pendirian yayasan yang disahkan Kemenkum HAM, izin 
pendirian, tidak menyelenggarakan program kelas jauh, menyelesaikan laporan pangkalan data perguruan tinggi, memiliki akreditasi dari Badan Akreditasi Nasional Perguruan Tingg atau sudah mengajukan, dan tidak dilanda konflik internal dalam masalah kepemilikan. Faktor lain yang membuat PTS tidak sehat adalah memiliki dosen yang rangkap jabatan menjadi guru."

Fenomena tersebut di atas menunjukkan pengukuran kinerja perguruan tinggi harus dilakukan. Pengukuran kinerja merupakan usaha manajemen yang dilakukan secara periodik untuk mengetahui efektifitas penerapan sstrategi yang telah ditentukan oleh organisasi untuk mencapai keberhasilan tujuan. Sistem pengukuran kinerja dalam manajemen tradisional ditekankan pada aspek keuangan, karena ukuran keuangan ini mudah dilakukan sehingga kinerja personal yang diukur hanya berkaitan dengan aspek keuangan. Oleh karena itu dalam menghadapi lingkungan usaha yang dinamis tersebut perguruan tinggi perlu melakukan pengukuran kinerja manajemen dari aspek nonkeuangan, yang selama ini diabaikan dalam manajemen tradisional.

Informasi tentang kinerja organisasi dapat digunakan untuk mengevaluasi apakah proses kerja yang dilakukan organisasi selama ini sudah sejalan dengan tujuan yang diharapkan atau belum. Akan tetapi dalam kenyataannya banyak organisasi yang justru kurang atau bahkan tidak jarang ada yang tidak mempunyai informasi tentang kinerja dalam organisasinya. Balanced Scorecard adalah konsep yang mengukur kinerja suatu organisasi dari empat perspektif yaitu perspektif finansial, perspektif customer, perspektif proses bisnis internal, perspektif pertumbuhan dan pembelajaran. Konsep Balanced Scorecard ini pada dasarnya merupakan penerjemahan strategi dan tujuan yang ingin dicapai oleh suatu perusahaan atau suatu instansi baik itu instansi pemerintahan maupun instansi pendidikan dalam jangka panjang, yang kemudian diukur dan dimonitor secara berkelanjutan. Konsep ini akan membantu untuk melakukan pengukuran kinerja secara lebih komprehensif dan akurat.

Beberapa penelitian tentang pengukuran kinerja dengan balanced scorecard telah dilakukan diantaranya oleh Kustiyahningsih (2010), penelitian ini mengukur dan menganalisa kinerja Fakultas Teknik Universitas Trunojoyo dari masingmasing jurusan yang ditinjau dari empat perspektif balanced scorecard yang dikombinaskan dengan pembobotan analytic hierarchy process (AHP). Pertiwi, dkk dalam proceeding Konferensi Nasional Sistem Informasi http://www.researchgate.net: diakses 23 Juni 2016), melakukan penelitian tentang balanced scorecard sebagai alat ukur kinerja perguruan tinggi (IT Telkom).

Perguruan tinggi memiliki andil yang sangat berperan dalam seluruh proses penciptaan sumberdaya manusia yang berkualitas dan berkompetensi. Untuk mewujudkan perguruan tinggi yang sehat dibutuhkan dukungan dari semua unsur pemangku jabatan (stakeholders) yaitu; pembuat dan pengawas kebijakan, pegawai sebagai pelaksana kebijakan, masyarakat perguruan tinggi dan masyarakat umum sektor produktif, asosiasi profesi, lembaga swadaya masyarakat, alumni perguruan tinggi, media masa, 
serta kelompok masyarakat lainnya. Berkaitan dengan latar belakang tersebut diatas, maka tujuan penelitian ini adalah untuk menganalisis kinerja di salah satu universitas di Kabupaten gresik dengan balanced scorecard.

\section{TINJAUAN PUSTAKA}

Penelitian tentang pengukuran kinerja dengan balanced scorecard telah dilakukan oleh Kustiyahningsih (2010), penelitian ini bertujuan untuk mengukur dan menganalisa kinerja Fakultas Teknik Universitas Trunojoyo dari masing-masing jurusan yang ditinjau dari empat perspektif balanced scorecard yang dikombinaskan dengan pembobotan analytic hierarchy process (AHP). Hasil penelitian tersebut adalah dengan kombinasi kedua metode yaitu balanced scorecard dan AHP dapat meningkatkan kinerja performance Fakultas Teknik dan sebagai acuan untuk pengembangan strategi serta memudahkan manajemen mengetahui kinerja fakultas dan memberikan acuan perbaikan strategi peningkatan kinerja. Pertiwi, dkk dalam proceeding Konferensi Nasional Sistem Informasi (http://www.researchgate.net: diakses 23 Juni 2016) melakukan penelitian tentang balanced scorecard sebagai alat ukur kinerja perguruan tinggi (IT Telkom). Hasil akhir dari ini adalah; balanced scorecard dapat diterapkan untuk mengukur kinerja semua elemen atau bagian yang ada pada IT Telkom, kerangka kerja yang dilakukan dalam penelitian tersebut dapat mempermudah dalam implementasi balanced scorecard sebagai alat ukur kinerja IT Telkom, dan company scorecard dapat dijadikan acuan penilaian kinerja yang berisi ukuran kinerja yang telah dipetakan kedalam bagian-bagian yang bertanggung jawab di IT Telkom. Penelitian Yasa, dkk (http://portalgaruda.org: diakses tanggal 24 Juni 2016) mengukur kinerja Rumah Sakit Umum Parama Sidhi Singaraja dengan menggunkan balanced scorecard. Hasil penelitian ini adalah diketahui bahwa kinerja RSU Parama Sidhi Singaraja secara umum masih kurang. Hal tersebut ditunjukkan dengan hasil analisis dari masing-masing perspektif. balanced scorecard merupakan metode pengukuran kinerja yang baik digunakan karena balanced scorecard mengangkat aspek-aspek penting yang diabaikan oleh pengukuran kinerja secara tradisional.

\section{Kinerja Organisasi / Perusahaan}

Pengukuran kinerja didefinisikan sebagai suatu alat kontrol perusahaan yang bertujuan untuk memotivasi karyawan di dalam mencapai apa yang dikehendaki organisasi (Kaplan dan Norton, 2009:19). Menurut Mulyadi (2001:28) menyatakan bahwa pengukuran kinerja adalah penentuan secara periodik efektivitas operasional suatu organisasi, bagian organisasi dan personalnya berdasarkan sasaran, standar, dan kriteria yang telah ditetapkan sebelumnya. Berdasarkan pengertian-pengertian di atas dapat disimpulkan bahwa pengukuran kinerja merupakan usaha manajemen yang dilakukan secara periodik untuk mengetahui efektifitas penerapan strategi- strategi yang ditentukan perusahaan untuk mencapai keberhasilan tujuan perusahaan.

Tujuan pengukuran kinerja menurut Siegel dan Marconi dalam Limawati (2003) adalah sebagai berikut.

1. Untuk mengarahkan kemajuan mereka pada satu atau lebih sasaran bisnis dalam hal kualitas produk dan jasa.

2. Untuk memotivasi karyawan dalam mencapai tujuan organisasi dan 
dalam mematuhi standar perilaku yang telah ditetapkan sebelumnya agar membuahkan tindakan dan hasil yang diinginkan.

3. Untuk meningkatkan efektifitas sebagai sebuah tim, membangun motivasi dan memberi imbalan atau penghargaan atas sebuah prestasi.

4. Untuk menekan perilaku yang tidak semestinya dan mendorong perilaku yang semestinya diinginkan melalui umpan balik hasil kinerja waktunya serta imbalan, baik yang bersifat instrinsik maupun ekstrinsik.

5. Membantu dalam penetapan standar dan target, sarana untuk kemajuan, memotivasi, mengkomunikasikan strategi organisasi dan mempengaruhi perubahan perilaku.

Sedangkan manfaat pengukuran kinerja (Mulyadi:2001) adalah; mengelola operasi organisasi secara efektif dan efisien melalui pemberian motivasi karyawan secara maksimal, membantu pengambilan keputusan yang berhubungan dengan karyawan, seperti promosi, transfer dan pemberhentian karyawan, mengidentifikasi kebutuhan dan pelatihan dan pengembangan karyawan mengenai bagaimana atasannya menilai kinerja mereka.

\section{Pengukuran Kinerja dengan Balanced Scorecard}

Balanced scorecard adalah pengukuran kinerja perusahaan yang modern dikembangkan oleh Robert S. Kaplan dan David P. Norton dengan mempertimbangan empat perspektif (yang saling berhubungan) yang merupakan penerjemahan strategi dan tujuan yang diingin dicapai oleh suatu perusahaan dalam jangka panjang, yang kemudian diukur dan dimonitor secara berkelanjutan. Pengukuran kinerja dengan balanced scorecard muncul karena adanya pergeseran tingkat persaingan bisnis dari industrial competition ke information competition, sehingga mengubah alat ukur atau acuan yang dipakai oleh perusahaan untuk mengukur kinerjanya. Balanced scorecard dalam mengukur kinerja menggunakan 4 perspektif yaitu:

1. Financial. Ukuran generik yaitu tingkat pengembalian investasi dan nilai tambah ekonomi

2. Customer. Ukuran generik yaitu kepuasan, retensi, pangsa pasar, dan pangsa rekening

3. Internal Bussiness Process. Ukuran generik yaitu mutu, waktu tanggap, biaya, dan pengenalan produk baru

4. Learning and Growth. Ukuran generik yaitu kepuasan pekerja dan ketersediaan sistem informasi

Perspektif non keuangan adalah bagian yang juga penting yaitu apabila diperhatikan maka pada akhirnya dapat mendongkrak kinerja keuangan yang merupakan keinginan utama dari pemegang saham. Berikut ini hubungan antara ke-4 Perspektif dalam balanced scorecard (Kaplan dan Norton: 2000:28).

\section{METODE PENELITIAN}

Penelitian ini menggunakan pendekatan penelitian kualitatif. Pendekatan penelitian ini menitik beratkan pada studi kasus yang menghasilkan data diskriptif berupa kata-kata tertulis atau lisan dari orangorang atau pelaku yang diamati. Studi Kasus adalah penelitian tentang status subyek penelitian yang berkenan dengan suatu fase spesifik atau khas dari keseluruhan personalitas.

Teknik pengambilan data yang akan dilakukan dalam penelitian ini; observasi dengan mengadakan pengamatan secara langsung terhadap 
obyek penelitian, wawancara terhadap pihak universitas untuk memperoleh informasi yang terkait dengan sistem pengukuran kinerja dan dokumentasi data universitas berupa dokumen seperti laporan keuangan dan data lain yang berhubungan dengan pengukuran kinerja perusahaan. Sedangkan teknik analisis data penelitian adalah sebagai berikut:

1. Menggambarkan visi, misi, strategi dan pengukuran kinerja di universitas.

2. Melakukan evaluasi terhadap sistem dan hasil pengukuran kinerja yang selama ini digunakan oleh pihak universitas dengan menggunakan kerangka balanced scorecard.

\section{HASIL DAN PEMBAHASAN}

\section{Visi Universitas}

Menjadikan Universitas unggul, mandiri, berjiwa entrepreneurship, berlandaskan pada nilai nilai islami.

\section{Misi Universitas}

1. Menyelenggarakan pendidikan, penelitian dan pengabdian masyarakat yang berkualitas dan terukur melalui pendidikan senyatanya (the realistic education)

2. Menyelenggarakan Universitas yang mandiri dengan tata kelola yang baik (Good University Governace)

3. Menyelenggarakan pendidikan ke arah kewirausahaan yang islami (Islamic Entrepreneurship)

\section{Tujuan Universitas}

a. Menjadi universitas yang unggul di bidang ilmu pengetahuan, teknologi dan seni dan menghasilkan lulusan berkualitas yang mengamalkan nilai-nilai Islam,

b. Menjadi universitas yang mandiri dengan tata kelola yang baik (Good University Governance)

c. Menjadi universitas yang mengembangkan nilai nilai interpreneurship yang islami.

\section{Perencanaan Strategis universitas}

Titik berat rencana trategi pengembangan universitas ini adalah aspek strategis dalam penyelenggaraan dan pengembangan universitas. Aspek strategis yang dimaksud meliputi:

1. Kinerja penyelenggaraan pendidikan.

2. Kinerja penyelenggaraan penelitian dan pengabdian kepada masyarakat.

3. Kinerja manajemen universitas yang meliputi bidang manajemen sumberdaya insani, keuangan, sumberdaya fisik, pengembangan kampus, administrasi akademik, pengembangan perpustakaan, dan teknologi informasi.

4. Budaya organisasi dan iklim akademik.

5. Jaringan kerjasama (networking). Berdasarkan wawancara dengan Rektor universitas (2016) menyatakan: "Dengan penetapan visi dan misi universitas, diharapkan mahasiswa memiliki jiwa entrepreneur berlandaskan nilai-nilai Islam karena nilai- nilai Islam dalam entrepreneur seringkali ditinggalkan. Tetapi khusus mahasiswa Fakultas Ekonomi harapannya tidak hanya memiliki jiwa entrepreneur tapi juga bisa menjadi entrepreneur yang Islami. Menterjemahkan sukses menurut orang sukses, bukan orang awam.

Sukses itu kan mesti yang utama punya duit tapi "Sukses" menurut orang sukses adalah duit adalah akibat dari apa yang dilakukan selama ini sehingga duit itu hasil dari apa yang telah dupayakan. Sama seperti balanced scorecard dengan kinerja yang baik mulai aspek non keuangan yaitu pertumbuhan dan pembelajaran, proses bisnis internal, kepuasan pelanggan maka pada akhirnya kinerja 
keuangan juga akan baik." Universitas telah melakukan pengukuran kinerja, tidak hanya pada aspek keuangan tetapi juga non keuangan, sebagaimana pengukuran kinerja dalam balanced scorecard sebagaimana berikut:

\section{Perspektif Pertumbuhan dan Pembelajaran (Learning and Growth)}

Dari aspek Learning and Growth yakni ukuran generik yaitu kepuasan pekerja dan ketersediaan sistem informasi, Dalam upaya pencapaian kepuasan pekerja, universitas telah melakukan berbagai aktivitas guna pencapian pertumbuhan dan pembelajaran organisasi yang baik melalui pengembangan studi lanjut, pelatihan, workshop, seminar. Selain itu universitas memberikan kesejahteraan kepada dosen dan karyawan selain gaji pokok, tunjangan fungsional dosen, tunjangan penunjang akademik, tunjangan kekaryaan bagi karyawan, tunjangan jabatan struktural bagi pejabat sruktural, tunjangan tambahan jabatan structural bagi pejabat struktural.

Selain itu pegawai tetap juga diberikan tunjangan natura. Kesejahteraan lainnya yang diberikan adalah pegawai yang cacat karena menjalankan tugas diberi santunan cacat, pegawai yang meninggal dunia kepada ahli warisnya diberikan uang duka, pegawai yang menikah diberi

\begin{tabular}{|c|c|c|c|c|c|}
\hline Keterangan & $\begin{array}{c}\text { Proses } \\
\text { seleksi }\end{array}$ & $\begin{array}{c}\text { Kesempatan } \\
\text { pengembangan } \\
\text { diri }\end{array}$ & $\begin{array}{c}\text { Sistem } \\
\text { penilaian } \\
\text { kinerja }\end{array}$ & $\begin{array}{c}\text { Kompens } \\
\text { asi }\end{array}$ & $\begin{array}{c}\text { Sistem } \\
\text { pengembangan } \\
\text { karir }\end{array}$ \\
\hline Dosen & 3,20 & 3,45 & 3,50 & 3,80 & 3,60 \\
\hline Karyawan & 3,20 & 3,50 & 3,42 & 3,40 & 3,44 \\
\hline
\end{tabular}

Sumber: Badan Penjamin Mutu: 2015

Berdasarkan tabel 1 tersebut di atas, dosen dan karyawan di universitas

santunan pernikahan, tunjangan hari raya, gaji ke-13. Selain itu juga diberikan uang lembur jika ada perintah lembur dari atasan.

Pegawai di universitas juga diberikan penghargaan jika memenuhi kriteria tertentu berupa kenaikan golongan reguler, pilihan, istimewa, dan pengabdian. Demikian juga tentang sanksi, universitas mempunyai peraturan tentang pelanggaran dan sanksi bagi pegawai baik sanksi ringan, sedang, maupun berat. Evaluasi kinerja bagi dosen dilakukan 2 (dua) kali dalam setahun aspek nilai bagi dosen non structural adalah; pengajaran, penelitian, pengabdian serta aspek kedisiplinan. Sedangkan bagi dosen tetap yang menjabat struktural aspek yang dinilai adalah; aspek teknis, perilaku, potensi pegawai, manajerial, dan kedisiplinan. Tingkat penilaian secara kualitatif dan dinyatakan secara kuantitatif dengan score 1 sd. 4. Hasil evaluasi dan monitoring dibidang pengajaran yaitu dari segi kehadiran dosen, rata-rata kehadiran dosen adalah $78,7 \%$ dari jumlah keseluruhan pertemuan perkuliahan. Sedangkan dari aspek penelitian dan pengabdian pada masyarakat, masing-masing dosen tetap diberi kesempatan melakukan kegiatan penelitian dan pengabdian sebanyak satu (1) kali setiap tahun anggaran akademik. Kepuasan dosen dan karyawan atas sistem pengelolan Sumber Daya Manusia (SDM) adalah sebagai berikut: 
Perspektif Bisnis Internal (Internal Bussiness Process)

Internal Bussiness Process yakni ukuran generik yaitu mutu, waktu tanggap, biaya, dan pengenalan produk baru. Dalam aspek bisnis internal, universitas telah melakukan beberapa upaya untuk meningkatkan mutu dengan cara:

1. Mendisain kurikulum sesuai dengan kebutuhan para stakeholders dan melakukan peninjauan secara berkala setiap 4 (empat) tahun sekali. Selain itu proses monitoring dan evaluasi pengembanga kurikulum dilakukan setiap 1 (satu) tahun sekali untuk memastikan apakah sudah diimplementasikan dengan baik di semua program studi yang ada di universitas dan mengetahui apakah ada permasalahan dalam implementasi dan melakukan tindakan preventif seandainya terjadi penyimpangan.

2. Melaksanakan pengkajian dan pengembangan sistem dan mutu pembelajaran serta penelitian dan pengabdian pada masyarakat

3. Menjamin pelaksanaan kebebesan akademik melalui; kegiatan kuliah ahli, seminar, workshop, lesson study

4. Melakukan perencanaan dan pengalokasian dana dengan mekanisme rapat kerja dengan mengkombinasikan mekanisme buttom up dan top down

5. Membuat laporan keuangan secara periodik dan diaudit oleh Kantor Akuntan Publik (KAP) dan Lembaga Pembina dan Pengawas Keuangan (LPPK) yayasan.

6. Menetapkan biaya pendidikan dengan melibatkan pimpinan di universitas dan memberikan kebijakan keringanan berupa beasiswa kepada yang berpotensi secara akademik dan kurang mampu

7. Melakukan pengelolaan sarana dan prasarana sesuai dengan stándar operasional prosedur (SOP) yang ada di universitas seperti; laboratorium, sarana kelas, kebersihan, perpustakaan, jaringan internet, sarana administrasi pendukung lainnya.

Hasil pengukuran terhadap penilaian belajar mengajar dan atmosfir akademik menunjukkan bahwa $80 \%$ mahasiswa menyatakan baik, sedangkan 20\% menyatakan cukup. Sedangkan tentang kegunaan program dan kurikulum menunjukkan 90\% mahasiswa merasa sesuai dengan profesi dan pengembangan karir masa depan. Mutu lulusan baik, dilihat dari rata- rata masa studi mahasiswa untuk S-1 ditempuh selama 4 tahun, dengan IPK lulusan rata-rata 3,23. (Badan Penjamin Mutu: 2015)

\section{Perspektif Pelanggan (Customer)}

Customer yakni ukuran generik yaitu kepuasan, retensi, pangsa pasar, dan pangsa rekening. Dari aspek pelanggan, aktivitas pengukuran layanan yang telah dilakukan berupa penilaian proses pembelajaran yang berisi 4 aspek yaitu kepribadian, pedagogik, profesional, dan layanan sosial yang diberikan oleh dosen kepada mahasiswa, dan hasilnya menunjukkan bahwa mahasiswa merasakan pelayanan yang diberikan sudah sangat baik dengan rata-rata nilai diatas 3,90 (Badan Penjamin Mutu: 2015).

Aktivitas lain guna meningkatkan kepuasan pelanggan yang telah dilakukan, sebagaimana data Badan Penjamin Mutu: 2015 menunjukkan bahwa dari aspek layanan perwalian yang telah dilakukan, mencakup 2 aspek yaitu; 
ketersediaan waktu dan kualitas layanan dosen dalam memotivasi. Hasil pengukuran menunjukkan sangat baik dengan rata-rata nilai diatas 3,71. Hasil layanan bimbingan skripsi mencakup 3 aspek yaitu; ketersediaan waktu, motivasi dan perhatian, kompetensi pembimbing. Hasil pengukuran menunjukkan bahwa mahasiswa merasakan sangat baik dengan ratarata nilai 3,69. Demikian juga hasil pengukuran layanan perpustakaan, laboratorium dan administrasi mencakup 3 aspek yaitu; kualitas sarpras, SDM administrasi, dan proses layanan yang diberikan menunjukkan bahwa mahasiswa merasakan sangat baik dengan nilai rata-rata 3,73 .

\section{Perspektif Keuangan (Financial)}

Financial yakni ukuran generik yaitu tingkat pengembalian investasi dan nilai tambah ekonomi. Return On investment (ROI). Berdasarkan hasil wawancara dengan Biro Keuangan Universitas (2016), ROI Universitas adalah sebesar $18 \%$ pada tahun 2014 dan meningkat menjadi $20 \%$ pada tahun 2015. Peningkatan angka ROI diatas menunjukkan bahwa dari sisi kinerja keuangan, universitas mengalami kenaikan yang positif. Tentu saja hal tersebut sejalan dengan berbagai upaya dan program yang telah dilakukan universitas guna mencapai peningkatan kinerja, baik aspek keuangan maupun non keuangan.

\section{SIMPULAN DAN SARAN}

Berdasarkan pembahasan dan analisis data diatas, disimpulkan bahwa:

1. Dari pengukuran perspektif Pertumbuhan dan Pembelajaran (Learning and Growth), yaitu ukuran generik kepuasan pekerja, dosen dan karyawan merasakan sistem pengelolaan di universitas sudah baik.

2. Dari pengukuran Bisnis Internal (Internal Bussiness Process), universitas telah melakukan berbagai program pembenahan proses internal guna meningkatkan mutu lulusan.

3. Dari perspektif Pelanggan (Customer) berupa penilaian proses pembelajaran yang berisi 4 aspek yaitu kepribadian, pedagogik, profesional, dan layanan sosial yang diberikan oleh dosen kepada mahasiswa, dan hasilnya menunjukkan bahwa mahasiswa merasakan pelayanan yang diberikan sudah sangat baik

4. Dari pengukuran Perspektif Keuangan (Financial), terjadi peningkatan angka ROI sebagai dampak kinerja non keuangan (Learning and Growth, Internal Bussiness Process dan Customer).

Adapun saran yang peneliti sampaikan adalah: dari beberapa pengukuran yang telah dilakukan, baik perspektif Pertumbuhan dan Pembelajaran, Proses Bisnis Internal, Pelanggan, dan Keuangan, pihak universitas perlu melakukan pengukuran dari aspek landasan nilai Islami sebagaimana visi dan misi yang telah ditetapkan.

\section{DAFTAR PUSTAKA}

Anthony, Robert N. dan Govindarajan, Vijay. 2005. Buku 2 Management Control System. Jakarta. Salemba Empat.

Hamid Edy Suandy. 2013. Membangun Brand dan Trik Jitu Perguruan Tinggi Mandiri, Berkualitas Menuju World Class University. Seminar di Ballroom Hotel Sheraton Yogyakarta. 
Selasa 23 April 2013

Kaplan, Robert S. and D.P Norton. 2000. Balanced Scorecard: Menerapkan Strategi Menjadi Aksi. Alih Bahasa: Peter R, Yosi Pasla . Jakarta. Erlangga.

Kustiyahningsih Yeni. 2010. Evaluasi Pengukuran Kinerja Fakultas Teknik Universitas Trunojoyo Menggunakan Balanced Scorecard dan AHP

Mulyadi. 1999. Sistem Perencanaan dan Pengendalian Manajemen: Sistem Pelipat ganda Kinerja Perusahaan, Edisi satu, Yogyakarta: Adiya Media . 2001. Balanced Scorecard: Alat Manajemen Kontemporer untuk Pelipat ganda Kinerja Perusahaan. Jakarta: Salemba Empat.

Nasir, Mohammad. 2003.Metodologi Penelitian. Cetakan Keempat, Penerbit Ghalia Indonesia. Jakarta.
Pertiwi, Anggi Putri, Danto Wasesa, Laksitowenong Kususma. Balanced Scorecard Sebagai Alat Ukur Kinerja Perguruan Tinggi (IT Telkom). http://www.researchgate.net, diakses tanggal 23 Juni 2016

Sugiyono, 2009, Metode Penelitian Kuantitatif, Kualitatif dan R\&D, Bandung: Alfabeta

Yasa, Gd Menari, Suwendra, I Wayan. Pengukuran Kinerja dengan Konsep Balanced Scorecard Pada Rumah Sakit Umum Sidhi Singaraja http://portalgaruda.org, diakses tanggal 24 Juni 2016

http://puslit.perta.ac.id/journals/acou nting, diakses tanggal 2 Juli 2016

https://nasional.tempo.co/read/73026 6/pemerintah-tutup-10perguruan- tinggi-swasta-dijawa- timur/full\&view=ok, diakses tanggal 2 Juli 2016 